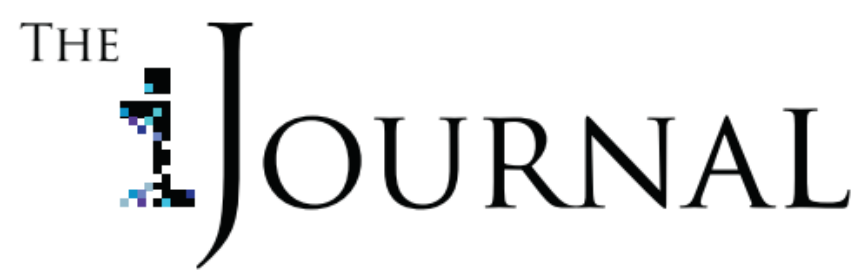

\title{
Impact of Promotional Events and Routes of Access on OurDigitalWorld's Digital Newspaper Collection
}
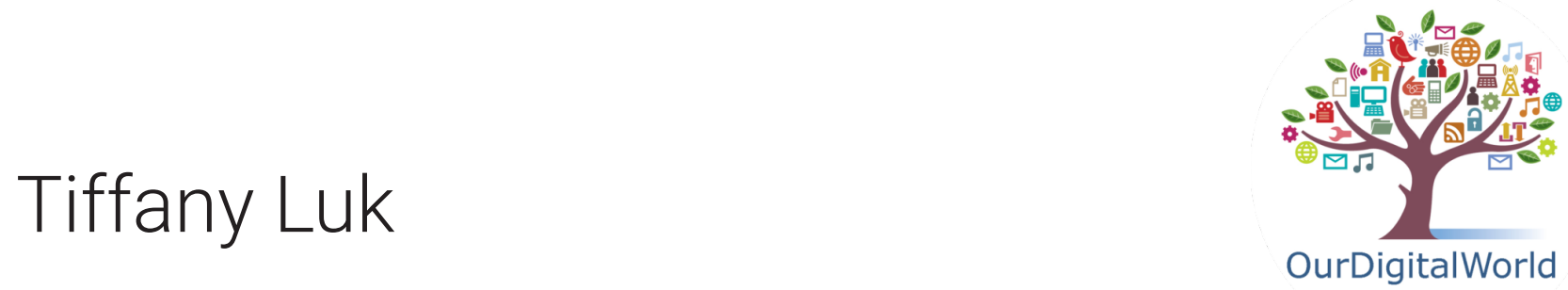

\section{Abstract}

A site traffic analysis study of 24 newspaper sites ${ }^{1}$ from OurDigitalWorld's (ODW) digital newspaper collection and the Ontario Community Newspaper ( $\mathrm{OCN}$ ) aggregate site was completed between 2016 and 2018. Digital newspapers provide access to past and current heritage news, vital statistics, and newspaper clippings. Securing grants from government agencies is essential for local heritage organizations to launch, build, and maintain their digitization initiatives in order to ensure the continuity of local culture and heritage of the past to people of the future. Thus, assessing the impact of (e.g. site usage, Web presence) and routes of Web access to digital newspaper collections is important to determine promotional strategies to increase usage and awareness of the collections. Recommendations were made for ODW, public libraries, and heritage organizations to increase the Web presence and awareness of ODW's digital newspaper collection and to educate users about the various uses of the newspaper sites.

1 Refer to Appendix A for the full list of sites examined.

\section{Keywords}

Digital newspaper collections, site traffic analysis, web presence, user awareness, user education 


\section{Introduction}

ODW is a non-profit organization that "supports digital stewardship of community cultural heritage" by collaborating with libraries, archives, museums, historical societies, and community groups to build and maintain digital collections (ODW, 2018c). ODW has the fourth largest digital newspaper collection in the world (ODW, 2018a). The collection consists of two major newspaper portals, Ontario Community Newspaper (OCN) and INK' , which provide open access to hundreds of local Ontario newspaper titles from 1810 to present, spanning two million pages (ODW, 2018a).

Digital newspapers provide access to heritage news, birth, marriages, and death (BMD) index records, and newspaper clippings in electronic format, allowing visitors to virtually access the collection while the originals remain on-site (ODW, 2018b). Securing grants from government agencies is essential for local heritage organizations to launch, build, and maintain their digitization initiatives in order to ensure the continuity of local culture and heritage. Thus, the purpose of this study is to assess the impact of ODW's digital newspaper collections and examine the routes of access in order to determine strategies to increase usage and awareness of the collections.

\section{Methodology}

Data was obtained from Google Analytics from March 1, 2016 to March 31, 2018 for the 24 individual newspaper sites from ODW's digital newspaper collection and from the Ontario Community Newspaper (OCN) aggregate site ${ }^{2}$. Quantitative data (e.g. number of users, number of sessions) and qualitative data (e.g. source/ medium URLs) were exported from Google Analytics as CSV files and copied onto Excel for data analysis. The data from Excel was then analyzed (e.g. sorted into categories) and represented using visual representations (e.g. pie graphs) created with Excel.

Three types of analysis, namely site user analysis, routes of access, and peak usage analysis were used to analyze data from Google analytics. Site user analysis assessed the web presence and public awareness of the collection via the number of new and returning users. Source/Medium data (e.g. source URLs, referral links, and search engines) and the number of user sessions from the top 100 individual newspaper sites were used to infer target end users and potential Web locations to insert Web access points. Peak usage analysis of 12 newspaper sites with significant usage peaks and sites with low usage explored whether promotional events impacted site usage. This was done by using a procedural search strategy to match the date of the usage peak and the corresponding top three referrals URLs, if available, to find a potential promotional activity. The procedural search strategy included performing a series of searches on the library's event calendar, newsfeeds, and social 1 INK is a pilot project of ODW. It includes 52 community newspaper titles that have been scanned from microfilm to allow ease of access online (ODW, n.d.)

2 Refer to Appendix A for a list of newspaper sites studied. 
Luk / Impact of Promotional Events and Routes of Access

media pages, as well as performing specific keyword searches on a search engine (e.g. *Name of Library* AND "genealogy workshop").

\section{Findings and Interpretations}

\section{Overview}

An analysis of site usage and routes of access to 24 selected individual newspaper sites newspaper sites of ODW's digital newspaper collection and the OCN aggregate site was conducted to determine strategies to increase usage, Web presence and access, and for outreach and promotion of the collection. Findings for three parts of the study are described below along with graphical representations.

\section{Site User Analysis}

\section{Usage of Individual Newspaper Sites}

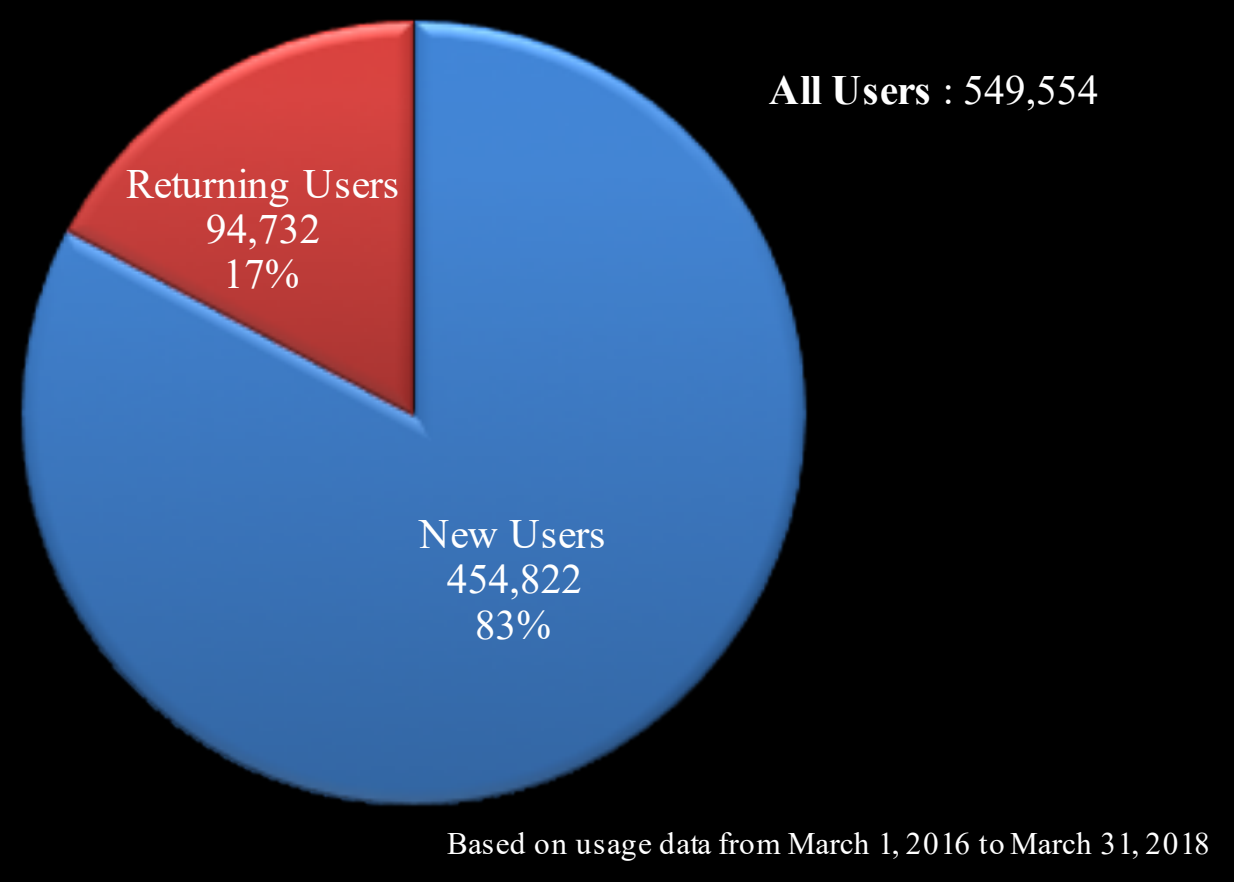

Figure 1: Average percentage of returning users and new users of 24 individual newspaper sites. 


\section{Usage of Ontario Community Newspaper Site}

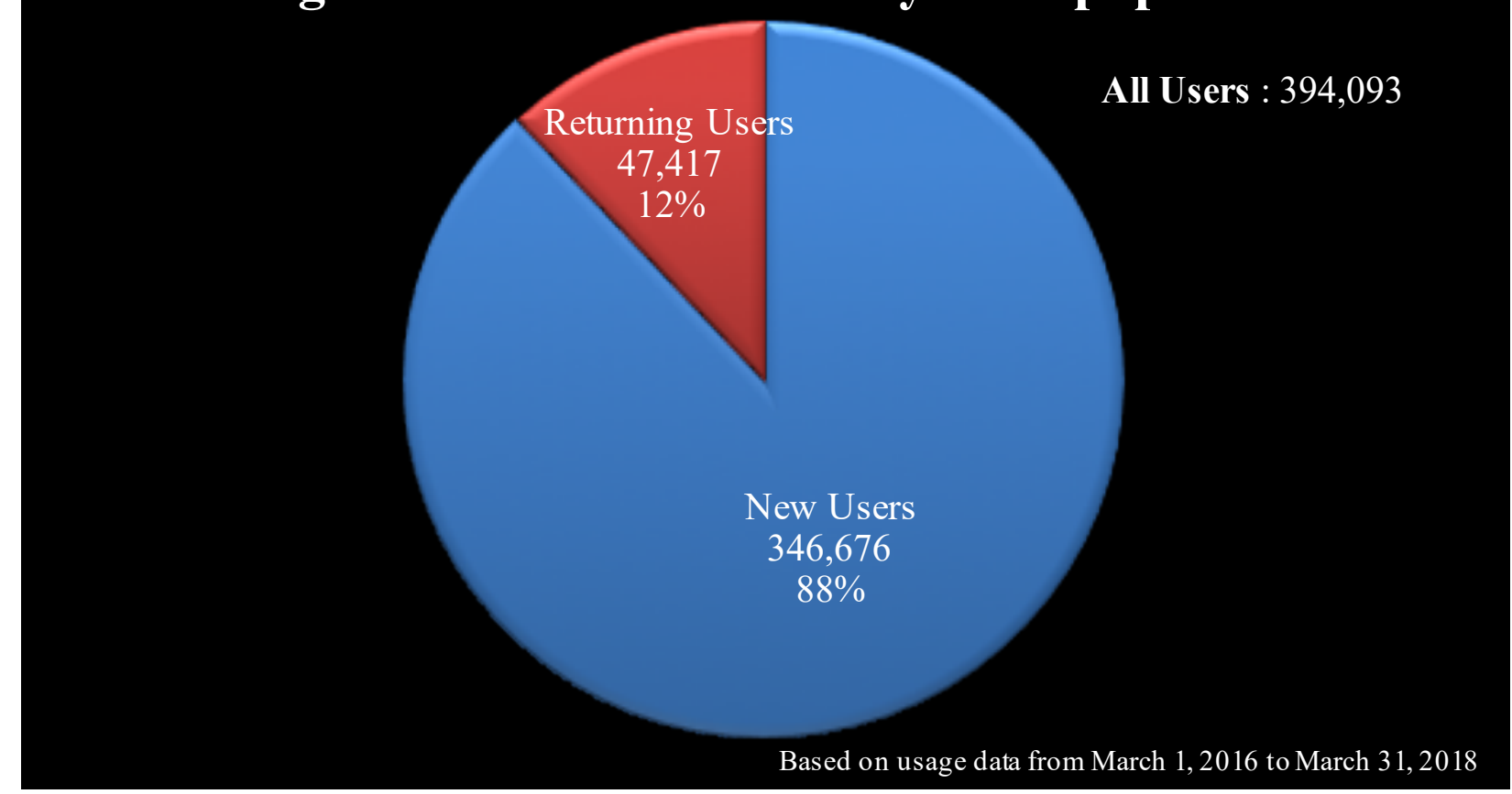

Figure 2: Percentage of returning users and new users for the Ontario Community Newspaper (OCN) aggregate site (i.e. http://news.ourontario.ca).

The low average percentage of returning users for individual newspaper sites (17\%) and the OCN aggregate sites (12\%) suggests that users may not be familiar with the site, might not have found the site to be useful, or the site was not easily accessible (Figures $1 \& 2$ ). The high percentage of new users for individual newspaper sites (83\%) and the OCN aggregate sites (88\%) may hint that most users are beginning to build awareness and discovering the usefulness of digital newspapers (Figures 1 \& 2). 


\section{Routes of Access}

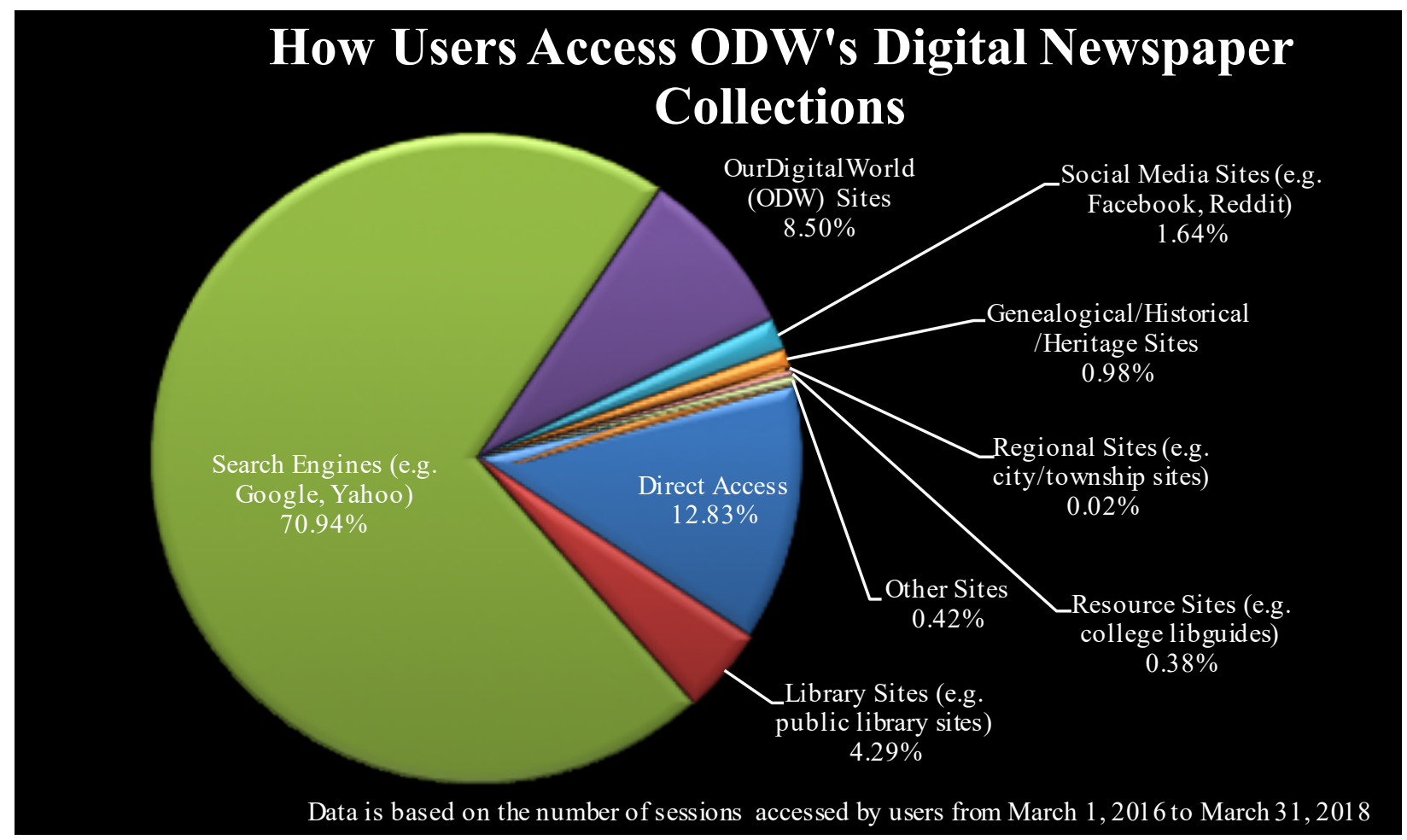

Figure 3: Routes of access to 24 individual newspaper sites and the Ontario Community Newspaper $(\mathrm{OCN})$ aggregate site.

The top four routes of access to the 24 individual newspaper sites and OCN aggregate site (based on the total number of web sessions) are search engines (70.94\%), direct access $(12.83 \%)$, ODW sites (8.50\%), and library sites (4.29\%) (Figure 3). Other sites of lower percentages are social media sites, genealogical, historical, and heritage sites, and resources sites (e.g. university LibGuides). The source URLs of the referrals infer that end users may be the general public (e.g. using sites for personal interest, part of a genealogy group), post-secondary students (e.g. doing research from a LibGuide), library staffs (e.g. dedicated local history and genealogy page), historians, and genealogists.

\section{Peak Usage Analysis}

The 12 selected newspaper sites with significant peaks identified for Peak usage analysis are as follows: Clarington Digital Newspaper Collection, Halton Hills Newspapers, Kawartha Lakes Public Library Digital Archive, Lincoln Public Library Digital Collections, Newmarket's Digital Newspaper Project, Orillia News, Views \& More, Oshawa Newspapers, Mississauga News, Richmond Public Library Digital Collections, Timmins Newspapers, Whitchurch-Stouffville Newspaper Index, and Woodstock Newspapers. Peak usage analysis was inconclusive as a result of the ambiguity of search results and the observation that library events are not being archived after one year on library websites and 
Luk / Impact of Promotional Events and Routes of Access

social media pages. However, the search process for promotional events provided insight and ideas of avenues to pursue for future promotional strategies (e.g. library's e-resource page, Facebook page, and Twitter account) and inferred on the pitfalls of sites with low usage (e.g. no corresponding library website, no links to newspaper or ODW sites).

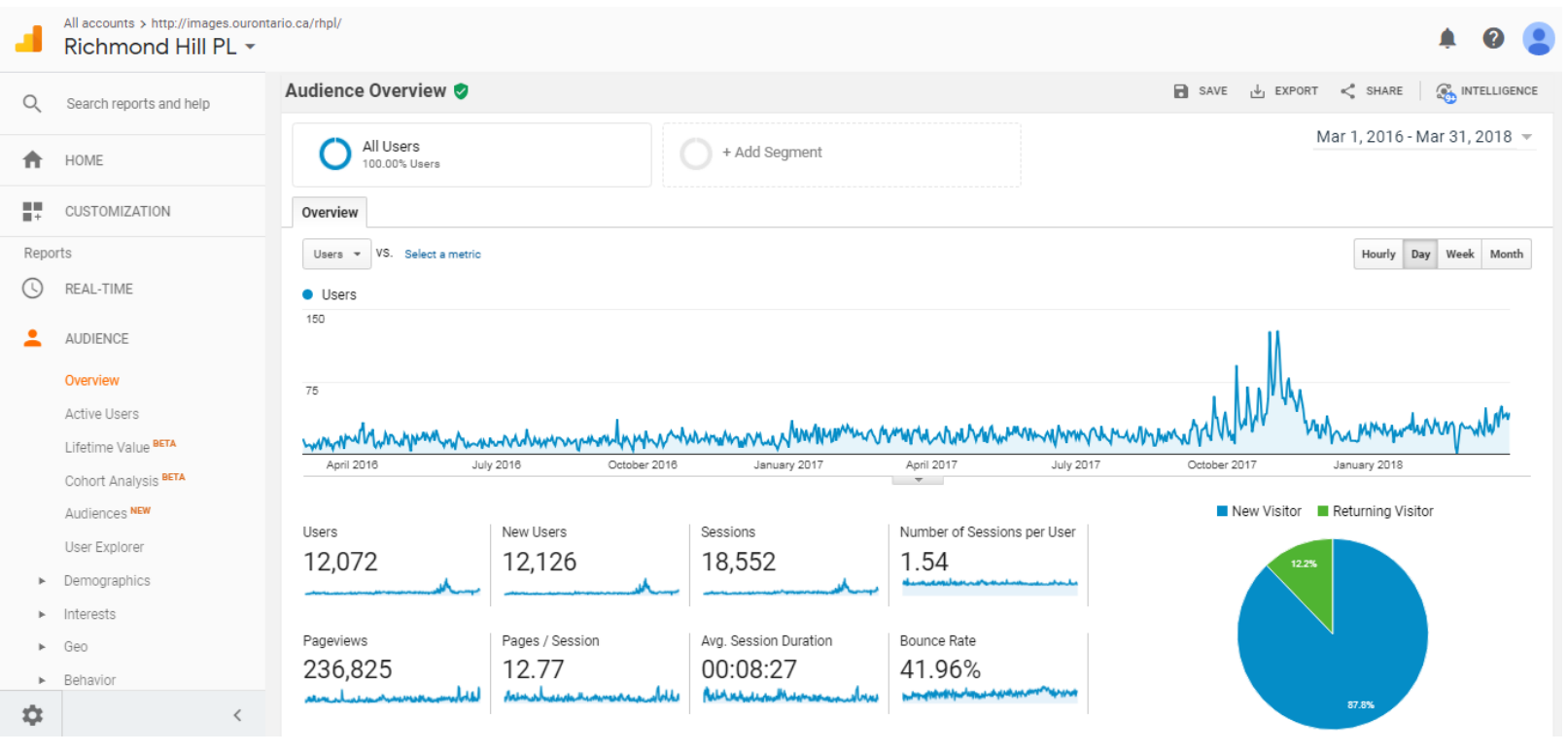

Figure 4: An example of a Peak Usage Analysis. The Google Analytics graph shows usage peaks (red arrow) of Richmond Hill Public Library's (RHPL) newspaper site based on the total number of users on a given date. The date of the usage peak and the top three referral URLs, if available are then correlated with possible a promotional activity through a procedural search strategy (e.g. search on library's event calendar, newsfeeds, and social media pages; keyword searches on a search engine). No corresponding promotional activity was found on the date of peak usage for RHPL.

\section{Recommendations}

Based on the findings and interpretations, there is a definite need to increase the Web presence and public awareness of ODW's individual digital newspaper collections by expanding the number of Web access points and increasing site usage through promotional and outreach activities for both partner organizations, such as libraries and heritage organizations, with ODW as the host organization. 
Luk / Impact of Promotional Events and Routes of Access

\begin{tabular}{|c|c|}
\hline Organization & Recommendations \\
\hline Public Libraries & $\begin{array}{l}\text { - Ensure that there is a page dedicated to local his- } \\
\text { tory and genealogy with links to local community } \\
\text { newspaper collections, other regional newspaper } \\
\text { sites if available, and the OCN site (i.e. news.ouron- } \\
\text { tario). } \\
\text { - Post concise user guides or short tutorial videos on } \\
\text { the local history and genealogy page to introduce } \\
\text { new users to the newspaper site functions and } \\
\text { possible uses (e.g. historical event research, genea- } \\
\text { logical research) and to remind returning users how } \\
\text { to fully utilize the site } \\
\text { Inform local historical societies and genealogical } \\
\text { groups about the newspaper collections and how to } \\
\text { use them } \\
\text { Publicize regular meetings (e.g. monthly) for any dedicat- } \\
\text { ed groups of patrons who do research on historical and } \\
\text { genealogical topics, and include regular events on the } \\
\text { library calendar } \\
\text { Actively use social media sites (especially existing Face- } \\
\text { book and Twitter pages created by libraries) to publicize } \\
\text { events such as genealogical workshops and database } \\
\text { research workshops and mention the newspaper site or } \\
\text { insert the link on the events page } \\
\text { Periodically publicize and raise awareness of newspaper } \\
\text { and ODW-related sites by reminding patrons about the } \\
\text { availability of these resources on their news feed or roll- } \\
\text { ing-images on the homepage } \\
\text { Public libraries whose library page is part of a township } \\
\text { or municipal site, such as Nipigon Public Library and the } \\
\text { Mississauga Library System, could reach out to the town } \\
\text { or municipality offices to ensure that a link to their news- } \\
\text { paper site is included on the library page }\end{array}$ \\
\hline $\begin{array}{l}\text { Related external organizations: } \\
\text { town or city offices, historical and } \\
\text { genealogical societies }\end{array}$ & $\begin{array}{l}\text { Local historical and genealogical societies and regional } \\
\text { and township sites can consider inserting links to the } \\
\text { newspaper site and ODW sites on their resources page }\end{array}$ \\
\hline
\end{tabular}


Luk / Impact of Promotional Events and Routes of Access

\begin{tabular}{|c|c|}
\hline & $\begin{array}{l}\text { - Local historical and genealogical societies can also create } \\
\text { a general user guide and/or tutorial video to educate the } \\
\text { public about the newspaper site and ODW's digital news- } \\
\text { paper collection } \\
\text { - Post-secondary institutions in the region provide the } \\
\text { newspaper site links on the college or university's library } \\
\text { e-resources page }\end{array}$ \\
\hline OurDigitalWorld (ODW) & $\begin{array}{l}\text { - Continue to publicize outreach (e.g. webinars) and pro- } \\
\text { motional events (e.g. news articles) on the ODW news } \\
\text { feed, newsletter, Facebook page, and Twitter account to } \\
\text { increase public awareness } \\
\text { - Continuing to promote special collections on ODW's Twit- } \\
\text { ter account may help to promote the individual newspaper } \\
\text { sites and ODW-related sites } \\
\text { Reach out to local and regional organizations (e.g. local } \\
\text { genealogical group, historical societies, and township or } \\
\text { regional sites) and ask them to insert a link to ODW-related } \\
\text { sites } \\
\text { Advise all public libraries to insert link to corresponding } \\
\text { newspaper site and links to ODW-related sites on their } \\
\text { e-resources page and/or dedicated local history and gene- } \\
\text { alogy page } \\
\text { Advise public libraries to regularly remind patrons about } \\
\text { digital newspaper collections on their news feed or home- } \\
\text { page } \\
\text { Provide templates of user guides and short tutorial vid- } \\
\text { eos to public libraries and appropriate heritage organiza- } \\
\text { tions (e.g. genealogical boards, historical societies) and } \\
\text { post-secondary institutions to ease the task of creating } \\
\text { guides to educate and increase public awareness of } \\
\text { articles) to insert newspaper sites and ODW-related site } \\
\text { links on the resource and bibliography sections }\end{array}$ \\
\hline
\end{tabular}


Luk / Impact of Promotional Events and Routes of Access

\begin{tabular}{|l|l|}
\hline $\begin{array}{l}\text { Directly contact organizations where their newspaper sites } \\
\text { have low usage and/or no apparent usage peaks with } \\
\text { ways to increase site usage and Web presence (e.g. create } \\
\text { a local history and genealogy page, publicize newspaper } \\
\text { site on social media platform) }\end{array}$ \\
\hline
\end{tabular}

\section{Conclusion}

This site traffic study assessed the Web presence, public awareness, and the impact of past promotional events and activities on site usage of 24 newspaper sites from ODW's digital newspaper collection and the Ontario Community Newspaper $(\mathrm{OCN})$ aggregate site. The results from three analysis processes were inferred to provide recommendations to ODW and external organizations to increase Web access points and to determine effective promotional and outreach strategies to increase Web presence and site usage.

Public libraries corresponding to the newspaper sites could promote site usage and Web presence by increasing their routes of Web access and by using consistent promotional strategies. For example, libraries could ensure that their website includes a dedicated local history and genealogy webpage with user education resources (e.g. user guides or brief videos to help users find news articles). As well, libraries could publicize events relating to the newspaper sites (e.g. genealogy workshops) on the library's online calendar and social media pages to increase the public's awareness of these events.

Similarly, ODW could expand Web access points to newspaper sites by reaching out to local post-secondary institutions, local genealogical and historical societies, and township and regional sites to insert links to the newspaper sites and related resources on their websites. As well, they should continue publicizing events on their news blog and social media pages to increase public awareness of the digital newspaper collection.

By following the recommendations for promotion and outreach, users would gain a greater sense of familiarity with ODW's digital newspaper collection, thus increasing usage and ensuring the continuity of the collection in the times to come. 
Luk / Impact of Promotional Events and Routes of Access

\section{References}

OurDigitalWorld (ODW). (2018a). Digital Newspapers. Retrieved from https://ourdigitalworld.net/whatwe-do/digital-newspapers/

OurDigitalWorld (ODW). (2018b). Digitization Projects. Retrieved from https://ourdigitalworld.net/re sources/project-management-resources/

OurDigitalWorld (ODW). (2018c). Homepage. Retrieved from https://ourdigitalworld.net/

OurDigitalWorld (ODW). (n.d.). INK--ODW Newspaper Collection. Retrieved from http://ink.ourdigi talworld.org/about

Appendix A: List of 24 Newspaper Sites and Ontario Community Newspaper (OCN) Aggregate Site Analyzed

- $\quad$ Barrie (Full issues, 1855 - 1979, BMD index, 1847 - 1968) Barrie Public Library

- $\quad$ Brampton (News \& BMD index, 1914 - current) Brampton Public Library

- $\quad$ Clarington (Full issues 1868 - 2012) Clarington Public Library

- $\quad$ Cobourg (News \& BMD index, 1814 - current) Cobourg Public Library

- $\quad$ Durham (News \& BMD index, 1857 - 1992) West Grey Public Library

- $\quad$ Grey Highlands (Full issues \& Vital statistics, 1880 - 1958) Grey Highlands Public Library

- Grimsby (News \& BMD index, scattered years from 1888 - current) Grimsby Public Library \& Grimsby Historical Society Archive

- $\quad$ Halton Region (Full issues, News \& BMD indexing) which is composed of:

Burlington (News \& BMD index, 1899 - 2015) Burlington Public Library Halton Hills (Full issues, 1867 - current \& vital statistics 1855 - 2007) Halton Hills Public Library

Oakville (Full issues 1993 - current, News \& BMD index 1843 - 1992) Oakville Public Library

Kawartha Lakes (Full issues 1861-1959, News \& BMD index 1861-2012) Kawartha Lakes

Public Library

- $\quad$ Newmarket (Full issues \& Index, 1852 - 2010) Newmarket Public Library

- $\quad$ Orillia (News \& BMD index, 1868 - current) Orillia Public Library

- Oshawa (News \& BMD index, 1861 - current ) Oshawa Public Library

- $\quad$ Nipigon (Full issues, 1926 - 2016) Nipigon Public Library

- $\quad$ Peel Region (News \& BMD indexing) which is composed of: 
Luk / Impact of Promotional Events and Routes of Access

- $\quad$ Brampton (News \& BMD index, 1914 - current) Brampton Public Library

- $\quad$ Mississauga (News \& BMD index, 1999 - 2009) Mississauga Public Library

- $\quad$ Richmond Hill (Full issues 1857 - 1979 \& BMD index 1858 - 1862) Richmond Hill Public Library

- $\quad$ Timmins (News \& BMD index, 1910 - 1989) Timmins Public Library

- Whitby (Full issues, 1850 - 1997, News \& BMD index, 1850 - current) Whitby Public Library

- Whitchurch-Stouffville (Full issues 1871 to current \& BMD index 1856 - current) WhitchurchStouffville Public Library

- Woodstock (News \& BMD index, 1840 - current) Woodstock Public Library \& Oxford Historical Association

The 23 individual newspaper sites above were selected from the list of newspaper sites in the OurOntario.ca: Newspaper Index (http://www.ourontario.ca/holdings/News.html). Note that two of the newspaper sites, Halton News and the Peel Newspaper Index are small regional aggregate sites for two to three individual newspaper agencies.

The Ontario Community Newspaper (OCN) aggregate site (http://news.ourontario.ca/) allows access to all Ontario-based digital newspapers from ODW's collection. The 24th site, Lincoln Public Library Digital Collection newspaper site (not found on the list) was accessed via the OCN aggregate site. 